\title{
Opsoclonus-Myoclonus Syndrome Associated With West-Nile Virus Infection: Case Report and Review of the Literature
}

\author{
Răzvan Alexandru Radu ${ }^{1,2}$, Elena Oana Terecoasă ${ }^{1,2 *}$, Amalia Ene ${ }^{1}$, \\ Ovidiu Alexandru Băjenaru ${ }^{1,2}$ and Cristina Tiu ${ }^{1,2}$ \\ ${ }^{1}$ Department of Neurology, University Emergency Hospital Bucharest, Bucharest, Romania, ${ }^{2}$ Department of Clinical \\ Neurosciences, University of Medicine and Pharmacy Carol Davila, Bucharest, Romania
}

OPEN ACCESS

Edited by:

Avindra Nath,

National Institute of Neurological Disorders and Stroke (NINDS),

United States

Reviewed by:

Kevin Tan,

National Neuroscience Institute (NNI),

Singapore

Sanjeev Kumar Bhoi,

All India Institute of Medical Sciences

Bhubaneswar, India

*Correspondence:

Elena Oana Terecoasă

oana_ter@yahoo.com

Specialty section

This article was submitted to

Neuroinfectious Diseases,

a section of the journal

Frontiers in Neurology

Received: 24 July 2018 Accepted: 25 September 2018 Published: 16 October 2018

Citation:

Radu RA, Terecoasă EO, Ene A

Băjenaru OA and Tiu C (2018) Opsoclonus-Myoclonus Syndrome Associated With West-Nile Virus Infection: Case Report and Review of the Literature. Front. Neurol. 9:864. doi: 10.3389/fneur.2018.00864
Opsoclonus-myoclonus syndrome (OMS) is a very rare condition with different autoimmune, infectious and paraneoplastic aetiologies or in most cases idiopathic. We report the case of a 75-year-old woman who was admitted in our department in early fall for altered mental status, opsoclonus, multifocal myoclonus, truncal titubation and generalized tremor, preceded by a 5 day prodrome consisting of malaise, nausea, fever and vomiting. Brain computed tomography and MRI scans showed no significant abnormalities and cerebrospinal fluid changes consisted of mildly increased protein content and number of white cells. Work-up for paraneoplastic and autoimmune causes of OMS was negative but serologic tests identified positive IgM and IgG antibodies against West Nile virus (WNV). The patient was treated with Dexamethasone and Clonazepam with progressive improvement of mental status, myoclonus, opsoclonus and associated neurologic signs. Six months after the acute illness she had complete recovery. To our knowledge this is the 14th case of WNV associated OMS reported in the literature so far. We briefly describe the clinical course of the other reported cases together with the different treatment strategies that have been employed.

Keywords: opsoclonus-myoclonus syndrome, West-Nile virus, West-Nile encephalitis, outcome, treatment

\section{INTRODUCTION}

Opsoclonus-myoclonus syndrome (OMS) is a very rare condition characterized by erratic multidirectional eye movements without intersaccadic intervals accompanied by myoclonus affecting both the limbs and the trunk, cerebellar ataxia, tremor and encephalopathy (1). Most cases of OMS in adults are paraneoplastic or idiopathic $(2,3)$ but the syndrome may also occur in association with a wide spectrum of infections with different agents including several viruses (influenza, varicella, human herpes virus 6, HIV, enteroviruses, Epstein-Barr, Cytomegalovirus, Coxsackie, West Nile Virus), Borrelia, Salmonella, Mycoplasma pneumoniae or as a poststreptococcal syndrome (4). Although West Nile virus (WNV) is listed among infectious causes of OMS in almost all publications related to this topic, through a comprehensive electronic search for English language publications performed in April 2018 using Pubmed, Medline and Web of Science databases we identified only 13 reported cases of OMS associated with WNV infection.

We report a case of OMS associated with WNV encephalitis and review the clinical characteristics, outcome and treatment options of the other reported cases. 


\section{CASE REPORT}

A 75-year-old Caucasian woman was admitted in our department in early fall for altered mental status, opsoclonus, multifocal myoclonus, truncal titubation, and generalized tremor. She had been in usual health until approximately 5 days before, when she was admitted to an internal medicine ward for malaise, tachypnea, nausea, vomiting, and fever. At that moment the symptoms were considered to be suggestive for an upper respiratory tract infection and she was treated with antipyretics. During the fourth day of hospitalization the patient gradually became confused and developed involuntary muscle twitches of all limbs, tremor and "jerky eye movements" which prompted evaluation by a neurologist. Her past medical history consisted of arterial hypertension, diabetes mellitus and chronic autoimmune thyroiditis.

At admission in our department, the patient was somnolent, afebrile, not oriented to person, place and time and was only able to answer "yes" or "no" to simple questions. The pulse was 80 beats per minute, the blood pressure 150/90 $\mathrm{mmHg}$, the respiratory rate 21 breaths per minute and the oxygen saturation $96 \%$ while breathing ambient air. Neurological examination revealed mild nuchal rigidity, opsoclonus, bilateral and multifocal myoclonus, more severely affecting the arms than the legs, truncal titubation amplified during active movements, postural and intention tremor, bilateral palmomental reflex, and mild weakness of the right upper limb. She could not maintain a sitting position due to truncal titubation and severe myoclonus.

Initial work-up done in the Department of Internal Medicine was unremarkable with the exception of a mild inflammatory syndrome and mildly increased creatinine kinase levels. Brain computed tomography (CT) scan performed at admission in our department showed leukoaraiosis, without other significant changes. Lumbar puncture revealed normal opening pressure and the cerebrospinal fluid analysis identified 17 leukocytes $/ \mathrm{mm}^{3}$, mildly elevated albumin levels $(30.6 \mathrm{mg} / \mathrm{l}$, local reference range 5-20 mg/l) and normal glucose levels. The electroencephalogram showed slow bilateral frontal waves. At this point we established a presumptive diagnosis of rhombencephalitis with opsoclonus-myoclonus syndrome (OMS) and started work-up for likely causes. Contrast enhanced brain MRI performed 10 days after symptom onset identified bilateral relatively symmetrical scattered white matter hyperintensities, predominantly in the periventricular and subcortical regions, consistent with small vessel disease related changes and no other significant abnormalities. A CT scan of the chest, abdomen and pelvis was performed in order to search for a possible tumor. Results were normal with the exception of a small non-enhancing hypodense lesion in the right ovary which was not correlated with raised CA-125 levels and was considered by the gynecologist an incidental finding. Further work-up for infectious, paraneoplastic, and autoimmune causes of encephalitis (see Table 1) was unremarkable, except for positive IgM and IgG antibodies against WNV.

Upon transfer in our department the patient was immediately given empiric therapy with Ampicillin, Ceftriaxone, Vancomycin, and Dexamethasone to cover potential causes of encephalitis
TABLE 1 | Laboratory work-up.

\begin{tabular}{|c|c|c|}
\hline & Result & Reference range \\
\hline \multicolumn{3}{|c|}{ INFECTIOUS DISEASES SEROLOGY (SERUM TESTING) } \\
\hline Epstein-Barr Virus antibodies IgG & $594 \mathrm{U} / \mathrm{ml}$ & Negative $<20 \mathrm{U} / \mathrm{ml}$ \\
\hline Epstein-Barr Virus antibodies IgM & $<10 \mathrm{U} / \mathrm{ml}$ & Negative $<20 \mathrm{U} / \mathrm{ml}$ \\
\hline Mycoplasma pneumoniae antibodies IgG & $<9 \mathrm{U} / \mathrm{ml}$ & Negative $<9 \mathrm{U} / \mathrm{ml}$ \\
\hline Mycoplasma pneumoniae antibodies IgM & $<0.9 \mathrm{U} / \mathrm{ml}$ & Negative $<0.9 \mathrm{U} / \mathrm{ml}$ \\
\hline Mycoplasma pneumoniae antibodies IgA & $<9 \mathrm{U} / \mathrm{ml}$ & Negative $<9 \mathrm{U} / \mathrm{ml}$ \\
\hline Listeria Monocytogenes IgM/lgG & Negative & Negative \\
\hline West-Nile antibodies $\lg G^{1}$ & 2.58 & $<1.1$ (index) \\
\hline West-Nile antibodies $\lg M^{1}$ & 4.16 & $<1.1$ (index) \\
\hline West-Nile antibodies $\lg G^{2}$ & 3.25 & $<1.1$ (index) \\
\hline West-Nile antibodies $\operatorname{lgM}^{2}$ & 3.41 & $<1.1$ (index) \\
\hline \multicolumn{3}{|l|}{ ANTI-NEURONAL ANTIBODIES } \\
\hline $\begin{array}{l}\text { anti-Amphiphysin, anti-CV2, anti-PNMA2, } \\
\text { anti-Ri, anti-Yo, anti-Hu, anti-Recoverin, } \\
\text { anti-Sox1, anti-Titin }\end{array}$ & Negative & Negative (Immunoblot) \\
\hline \multicolumn{3}{|l|}{ TUMOR MARKERS } \\
\hline CEA & $5.4 \mathrm{ng} / \mathrm{ml}$ & $0-5.8 \mathrm{ng} / \mathrm{ml}$ \\
\hline$\alpha$-fetoprotein & $5.8 \mathrm{ng} / \mathrm{ml}$ & $0-9.5 \mathrm{ng} / \mathrm{ml}$ \\
\hline Neuron - specific enolase & $9.95 \mathrm{ng} / \mathrm{ml}$ & $<17 \mathrm{ng} / \mathrm{ml}$ \\
\hline CA $19-9$ & $26.6 \mathrm{U} / \mathrm{ml}$ & $0-37 \mathrm{U} / \mathrm{ml}$ \\
\hline CA 15-3 & $21.5 \mathrm{U} / \mathrm{ml}$ & $0-23 \mathrm{U} / \mathrm{ml}$ \\
\hline CA 125 & $21.7 \mathrm{U} / \mathrm{ml}$ & $0-35 \mathrm{U} / \mathrm{ml}$ \\
\hline \multicolumn{3}{|l|}{ OTHERS } \\
\hline Anti-voltage gated $\mathrm{K}$ channels antibodies & Negative & Negative \\
\hline NMDA receptor antibodies & Negative & Negative \\
\hline Glutamic Acid Decarboxylase-II antibodies & $<5 \mathrm{IE} / \mathrm{ml}$ & $<10 \mathrm{IE} / \mathrm{ml}$ \\
\hline
\end{tabular}

${ }^{1}$ Blood samples collected 8 days after clinical onset; ${ }^{2}$ blood samples collected 14 days after first test.

and Clonazepam as a symptomatic therapy for myoclonus. The antibiotics were discontinued after the results of the lumbar puncture. Within a couple of days, myoclonus showed visible improvement but the opsoclonus and the cognitive status remained unchanged. Two weeks later, the patient started to improve from the cognitive point of view, as she was more aware of her surroundings and became oriented in time and partly in space. A second electroencephalogram performed at this point showed normal cerebral activity. She was discharged 3 weeks after admission, being able to walk with unilateral support. Neurocognitive evaluation performed at discharge showed severe visuospatial deficit and cognitive impairment (Mini Mental Status score-MMSE-of 12 points, Clock drawing test 2/10 points).

During the following weeks her condition gradually improved and she began to perform more and more activities of daily living by herself. At the follow-up visit, performed 1 month after discharge, neurological examination was normal except for very mild action tremor and mild opsoclonus which was only evident at close examination. Her neurocognitive status greatly improved, as she had a MMSE score of 25 points. A second follow-up visit, performed 6 months after discharge, showed normal neurological examination with complete resolution of 
previous signs and symptoms. Neurocognitive evaluation was within accepted ranges for her age and intellectual background (MMSE 29 points, Clock drawing test 10/10 points).

\section{DISCUSSION}

\section{Epidemiology of West-Nile Virus}

WNV is a member of the Japanese encephalitis antigenic serocomplex, belonging to the family of Flaviviridae, which also includes Japanese encephalitis virus, St Louis encephalitis virus, Dengue Virus, Yellow Fever Virus and the emerging Zika Virus $(5,6)$. It was first identified in the West Nile province of Uganda in 1937 (7). Since the initial communication, several WNV outbreaks were reported in Africa and in the Middle East, but significant disease activity was identified in Europe and North-America only after 1990 (8). The first major outbreak in Europe was described in south-east Romania in 1996 (9). Nowadays, cases of WNV infection are reported in many European countries, but the incidence is higher in the central and southern regions (10).

In nature, $\mathrm{WNV}$ is maintained in a bird-mosquito-bird transmission cycle. Birds develop sustained viremia and are considered amplifier hosts while humans usually develop transient low-level serum viremia and are unlikely to act as a reservoir for the virus. Transmission to humans commonly occurs through the Culex Mosquito spp. but transmission by blood transfusion, organ donation, pregnancy, and lactation have also been identified or postulated (5).

WNV infections usually start in summer and peak in early fall due to the natural life cycle of the mosquitos $(9,11)$. Local risk factors that might contribute to WNV amplification in the environment include elevated ambient temperature, heavy rains, stagnant water sources and immunologically naive avian host reservoirs (12). The onset of symptoms of our patient and of two other reported cases of OMS associated with WNV infection was in the typical early fall period. Although there are no reported details about the season of disease onset for the other similar published cases, WNV infection should probably be highly considered and searched for in all cases of OMS of undetermined etiology with onset during early fall.

\section{West Nile Virus Infection and Symptoms}

Up to $70 \%$ of the individuals infected with WNV will remain asymptomatic or will develop only minor, non-specific symptoms while one third will present with West Nile fever or other rare forms of the disease $(13,14)$. The clinical picture of West Nile fever is indistinguishable from other flu-like illnesses and includes: fever, headache, malaise, myalgia, nausea, vomiting, abdominal pain, and a morbilliform or maculopapular rash $(13,15)$. Although symptoms are usually self-limited, some patients develop persistent complaints such as fatigue, memory impairment or headache $(16,17)$.

Neuroinvasive disease occurs in $<1 \%$ of patients who develop clinical manifestations of WNV infection and can manifest as one of the following three clinical entities: WNV meningitis, WNV encephalitis or acute flaccid paralysis (18). Established risk factors for neuroinvasive disease include: advanced age, history of cardiovascular disease, chronic kidney disease, hepatitis C infection, immunosuppression, and particular genomic determinants involving adaptive and innate immune response pathways (12).

Neuroinvasive mechanisms for WNV are not yet clarified with both haematogenous and trans-neural pathways being proposed (19). The most likely hypothesis suggests a transendothelial route of entry whereby the virus is trafficked through an altered blood brain barrier by infected leucokytes $(20,21)$. The different clinical phenotypes reported in neuroinvasive WNV infection might be explained by the innate differences in antiviral cytokines and interferon stimulated-genes expressed in different neural subtypes (22). Recent studies on experimental animal models identified a mutation in the interferon stimulated-gene Ifi27l2a which promotes location specific neuronal cell death. In Ifi2712 $\mathrm{a}^{-/-}$and WNV infected mice, neurons in the cerebellum, brainstem, and possibly spinal cord live longer and harbor higher WNV burden in the active phase of the disease (23).

The acute development of a rash during the initial phase of the disease is thought to be significantly more rare in patients who further develop WNV encephalitis (24), but the mechanisms underlying this finding are yet unknown. However, two of the reported cases of OMS associated with WNV infection developed rash over the neck and trunk during the early course of the disease. Our patient did not show any skin changes prior to or during hospitalization.

Patients with West Nile encephalitis most commonly present with altered mental status of different severity, ranging from mild confusion to severe encephalopathy and coma. Extrapyramidal disorders are commonly observed, myoclonus, and tremor being the most frequently described $(11,25,26)$. Ataxia and various ocular motility disorders, including nystagmus and opsoclonus are also consistently reported (27-30). Although West Nile infection was reported as a cause of rhombencephalitis (31), only 13 cases of OMS were described so far in the literature (see Table 2), the first case being published in 2004 (11). However, since many authors report cases of West Nile virus encephalitis in which myoclonus is accompanied by abnormal nystagmoid eye movements, the true incidence of OMS in WNV infection is probably underestimated $(11,27,40)$.

\section{Opsoclonus-Myoclonus Syndrome}

OMS is a rare disease in adults. A literature search regarding adult-onset OMS performed in 2012 identified $<150$ reported cases over a nearly 50 -year period.(2) When the syndrome is not considered idiopathic, the most frequent identified etiologies are either paraneoplastic, or para-infectious, but the exact mechanisms of the disease and the neural structures involved are still not completely elucidated, due to the small number of cases and the absence of comprehensive pre-clinical and clinical studies. Several hypotheses regarding the affected neurons and neurotransmitters in this disease have been proposed. The first hypothesis postulates that alterations in the membrane properties of the saccadic burst neurons reduce the efficacy of omnipause neurons in the nucleus raphe interpositus of the pons either through excessive postinhibitory rebound or through a malfunction of the glycine receptors. However, to date, no 


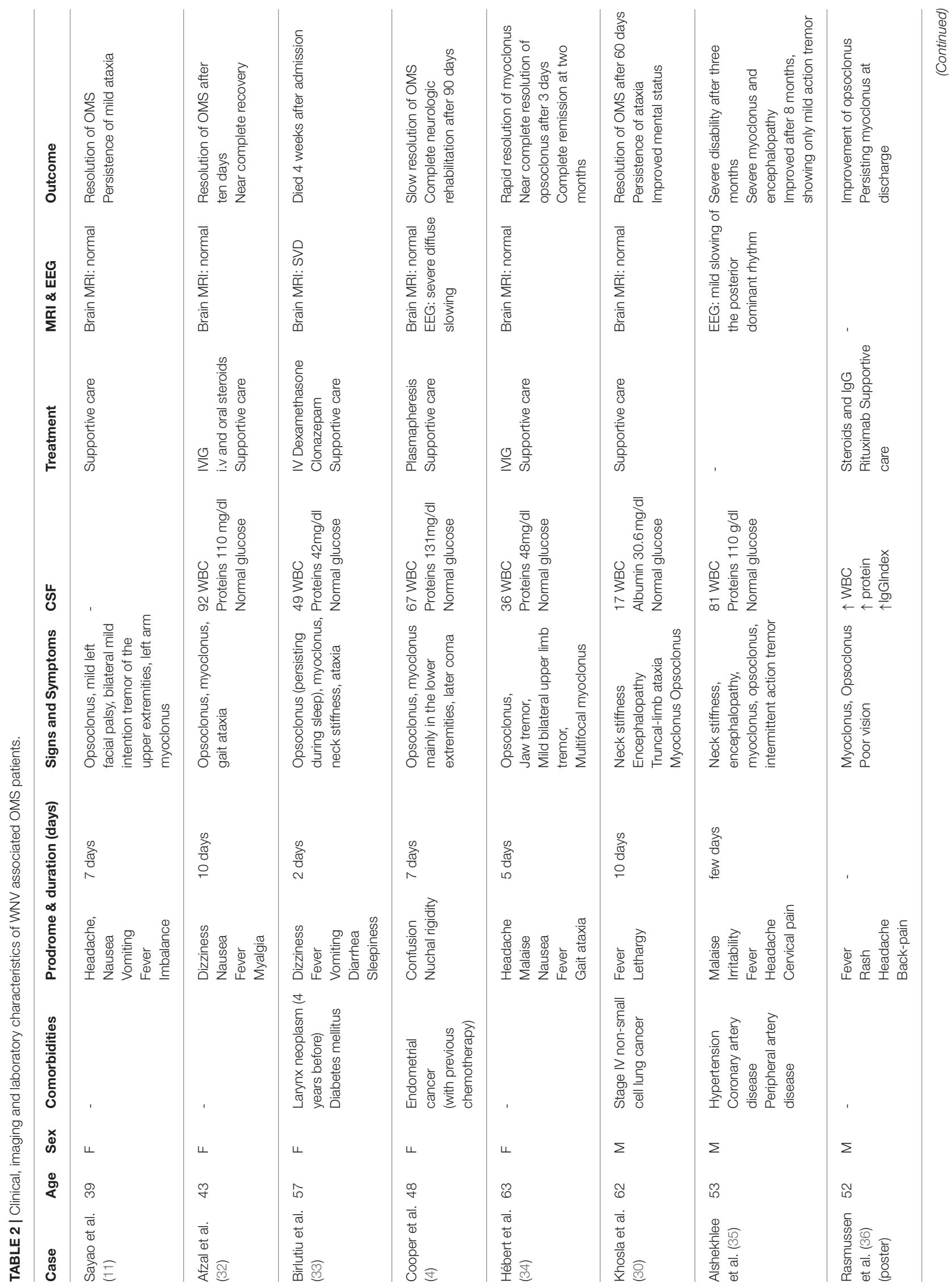




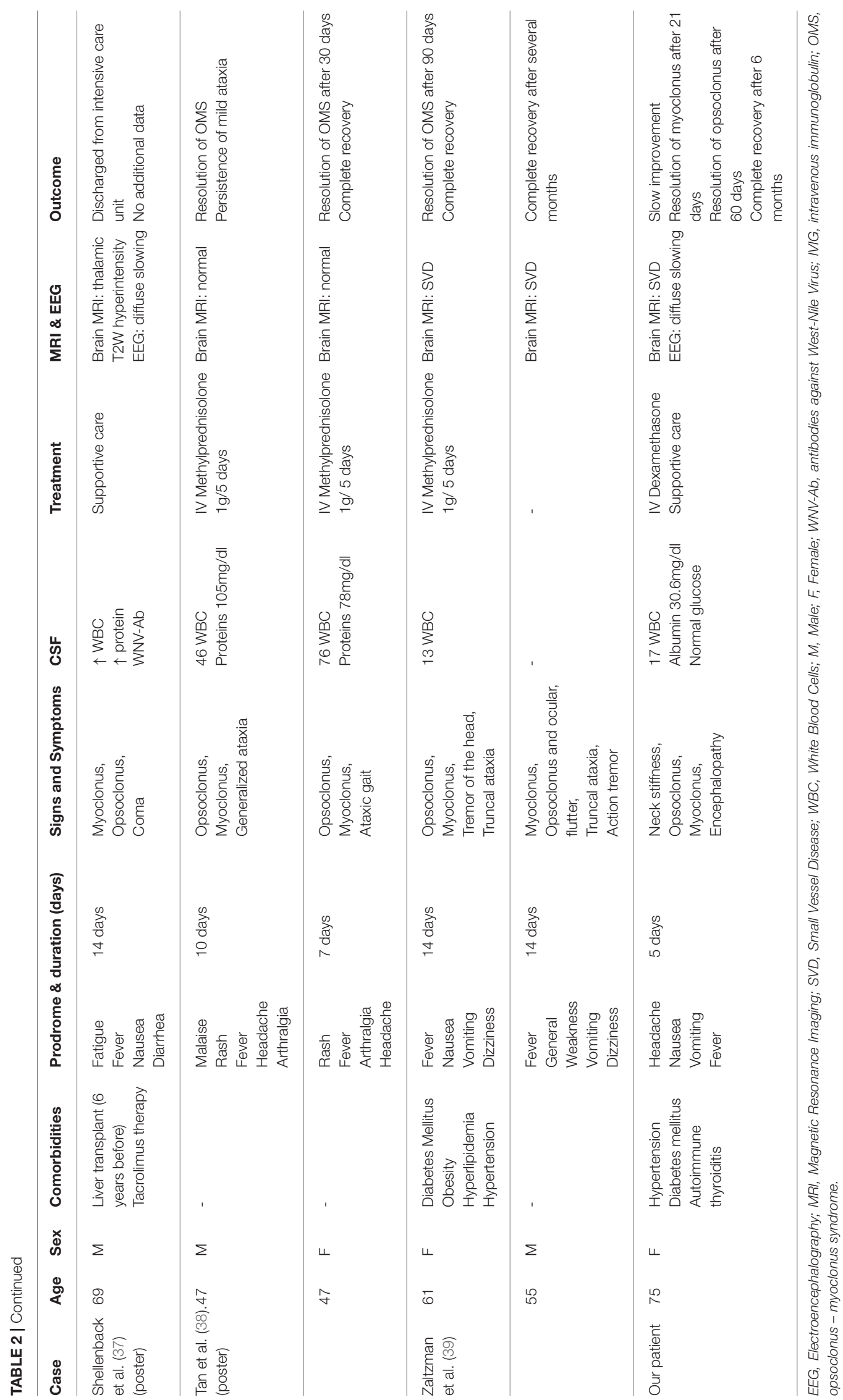


autopsy study showed any histological changes of the omnipause cells. The second hypothesis states that the malfunction of the Purkinje and granular cells in the dorsal vermis might lead to deafferentation of the fastigial nucleus and further on to a reduced inhibitory effect of the omnipause neurons, rendering saccadic neurons free to oscillate $(41,42)$. Several PET and fMRI studies have confirmed the hypermetabolism of the fastigial area in OMS patients, supporting this theory $(43,44)$. However, in WNV associated OMS the neuronal dysfunction probably extends to more widespread areas including the brainstem and the cerebellum, thus causing abnormally occurring discharges of saccadic generators in the lower pons. Furthermore, the acute dysfunction of the cerebellum could lead to a phenomenon of cerebello-cortical diaschisis which might explain the associated encephalopathy and the cognitive sequelae seen in some OMS patients $(45,46)$.

The main characteristics of all reported cases of WNV associated OMS are summarized in Table 2. Three of the patients had a history of cancer and underwent prior chemotherapy, one suffered liver transplantation 6 years before and received immunosuppressive treatment. Three other patients, all aged more than 50 years, had a history of arterial hypertension and two of them also had diabetes mellitus. With the exception of one case with a very severe and rapidly progressing clinical course, all other patients developed symptoms suggestive of West Nile fever 5 to 14 days before the occurrence of neurological signs. Altered mental status, which was not predictive of unfavorable outcome, was reported in 4 patients and usually developed after hospital admission. Of the two patients with deep coma, one made a full recovery whereas details about the long-term outcome of the other patient were not available.

Since the majority of reported patients with WNV associated OMS showed no supratentorial lesions on MRI, altered mental status and EEG changes could be interpreted either in the context of a diffuse gray matter dysfunction induced by the viral infection, or in the context of a secondary cerebellocortical network impairment. Previous research on this topic has shown that focal brainstem lesions can cause widespread cortical hypoperfusion with secondary dysfunction (45).

Details about brain MRI findings performed during the acute phase of the disease were available for 11 of the 13 reported cases of WNV associated OMS. No imaging findings consistent with brainstem involvement were identified. The most frequent reported findings were stigmata of small vessel disease in older individuals. Details about imaging findings on followup brain MRI scans performed weeks or months after the acute illness were not available. However, a recent small study comparing brain volumetry of healthy controls and patients with previous ocular flutter or opsoclonus showed a decrease of the cerebellar cortex volume with preservation of the cerebellar white matter volume and a subsequent decrease in both cortical and subcortical gray matter of the cerebral hemispheres despite the fact that most of the patients made a complete recovery (47). EEG findings were reported in few patients and showed a non-specific diffuse slow rhythm. Lumbar puncture changes were non-specific, most patients presenting mildly elevated white blood cell counts and CSF proteins with normal CSF glucose levels.

\section{Treatment of WNV Associated Opsoclonus-Myoclonus Syndrome}

Although several therapeutic agents were used for the treatment of WNV infection, none was proven to be efficient in a randomized controlled trial. The mainstay of therapy is primarily supportive. Reported therapeutic options that have been tried for WNV encephalitis include: immune $\gamma$-globulin (IVIG), plasmapheresis, WNV-specific neutralizing monoclonal antibodies, corticosteroids, ribavirin, interferon $\alpha-2 b$ and antisense oligomers (5). The rationale for immunoglobulin administration in WNV neuroinvasive disease is based on pre-clinical studies and individual case reports. However, one phase I/II randomized controlled trial in patients with WNV encephalitis which evaluated immunoglobulin therapy compared with placebo found no significant differences in outcome between groups (48). The lack of efficacy of immunoglobulin treatment might be explained by the fact that human patients already have IgM antibodies at the time of diagnosis and have cleared systemic viremia (49).

Two of the reported patients with WNV associated OMS were treated with IVIG and steroids, one with IVIG and Rituximab and one with plasmapheresis. The rest of the patients received treatment with corticosteroids or only supportive care. There was no significant difference in terms of speed and degree of neurologic improvement or persisting disability between patients.

\section{Prognosis of WNV Associated Opsoclonus-Myoclonus Syndrome}

Serious sequelae in WNV infection are usually encountered only in patients with neuroinvasive disease. Fatality rates reach $10-$ $30 \%$ in WNV encephalitis, older age and immunocompromised state being both consistently associated with poor outcome (50, 51). Significant improvement in WNV encephalitis survivors is usually seen during the first year after the acute disease but patient-reported clinical sequelae persist in up to $70 \%$ of $\mathrm{WNV}$-encephalitis patients even at 5 years after the initial event (52). Most patients complain of persistent fatigue, cognitive deficits, and muscle aches (51).

Data derived from the reported cases of WNV associated OMS suggest that this form of WNV infection has a more benign course compared to the classical WNV encephalitis. Out of the 13 reported cases in the literature till now, one patient died 4 weeks after onset but other 10 showed almost complete neurologic recovery several months after the acute illness. For two patients long term follow up was not available. Although male sex was reported to be associated with more severe illness and death (50), none of the reported male cases of WNV associated OMS died and the clinical course seems to have been similar in women and men. 


\section{CONCLUSION}

West Nile virus infection is probably an underdiagnosed cause of opsoclonus-myoclonus syndrome and this rare clinical entity is probably underrecognized in patients with West Nile virus infection. Although the number of cases of WNV associated opsoclonus-myoclonus syndrome reported in the literature till now is very small, it seems that the disease has a rather benign course and most patients recover almost completely after several months from disease onset. For the moment, there is no robust data to prove the superiority of any type of treatment against supportive care alone. Further studies regarding the susceptibility of different neural areas to West Nile virus infection will probably lead to a better understanding of the pathophysiology of this disease and the required treatment strategies.

\section{REFERENCES}

1. Wong AM, Musallam S, Tomlinson RD, Shannon P, Sharpe JA, Digre $\mathrm{K}$, et al. Opsoclonus in three dimensions: oculographic, neuropathologic and modelling correlates. J Neurol Sci. (2001) 189:71-81. doi: 10.1016/S0022-510X(01)00564-0

2. Klaas JP, Ahlskog JE, Pittock SJ, Matsumoto JY, Aksamit AJ, Bartleson JD, et al. Adult-onset opsoclonus-myoclonus syndrome. Arch Neurol. (2012) 69:1598. doi: 10.1001/archneurol.2012.1173

3. Dalmau J, Rosenfeld MR, Guichard M, Vignon G, Guichard M, Cabanne F, et al. Paraneoplastic syndromes of the CNS. Lancet Neurol. (2008) 7:327-40. doi: 10.1016/S1474-4422(08)70060-7

4. Cooper CJ, Said S. West nile virus encephalitis induced opsoclonusmyoclonus syndrome. Neurol Int. (2014) 6:5359. doi: 10.4081/ni.2014.5359

5. Petersen LR, Brault AC, Nasci RS. West nile virus: review of the literature. JAMA (2013) 310:308. doi: 10.1001/jama.2013.8042

6. Araujo AQC, Silva MTT, Araujo APQC. Zika virus-associated neurological disorders: a review. Brain (2016) 139:2122-30. doi: 10.1093/brain/aww158

7. Smithburn KC, Hughes TP, Burke AW, Paul JH. A neurotropic virus isolated from the blood of a native of Uganda. Am J Trop Med Hyg. (1940) s1-20:47192.

8. David S, Abraham AM. Epidemiological and clinical aspects on West Nile virus, a globally emerging pathogen. Infect Dis. (2016) 48:571-86. doi: 10.3109/23744235.2016.1164890

9. Tsai TF, Popovici F, Cernescu C, Campbell GL, Nedelcu NI, Peiris J, et al. West nile encephalitis epidemic in southeastern Romania. Lancet (1998) 352:767-71. doi: 10.1016/S0140-6736(98)03538-7

10. Rizzoli A, Jiménez-Clavero M, Barzon L, Cordioli P, Figuerola J, Koraka $\mathrm{P}$, et al. The challenge of West Nile virus in Europe: knowledge gaps and research priorities. Eurosurveillance (2015) 20:21135. doi: 10.2807/1560-7917.ES2015.20.20.21135

11. Sayao A-L, Suchowersky O, Al-Khathaami A, Klassen B, Katz NR, Sevick $\mathrm{R}$, et al. Calgary experience with West Nile virus neurological syndrome during the late summer of 2003. Can J Neurol Sci. (2004) 31:194-203. doi: $10.1017 /$ S031716710005383X

12. Montgomery RR, Murray KO. Risk factors for West Nile virus infection and disease in populations and individuals. Expert Rev Anti Infect Ther. (2015) 13:317-25. doi: 10.1586/14787210.2015.1007043

13. Zou S, Foster GA, Dodd RY, Petersen LR, Stramer SL. West nile fever characteristics among viremic persons identified through blood donor screening. J Infect Dis. (2010) 202:1354-61. doi: 10.1086/656602

14. Brown JA, Factor DL, Tkachenko N, Templeton SM, Crall ND, Pape WJ, et al. West nile viremic blood donors and risk factors for subsequent west nile fever. Vector Borne Zoonotic Dis. (2007) 7:479-88. doi: 10.1089/vbz.2006.0611

15. Orton SL, Stramer SL, Dodd RY. Self-reported symptoms associated with West Nile virus infection in RNA-positive blood donors. Transfusion (2006) 46:272-7. doi: 10.1111/j.1537-2995.2006.00710.x

\section{ETHICS STATEMENT}

Written informed consent was obtained from the pacient for the publication of this case report in accordance with the Declaration of Helsinki and all research was conducted following legal and ethical requirements of the University Emergency Hospital Bucharest.

\section{AUTHOR CONTRIBUTIONS}

AE: clinical assessment; RR: clinical assessment, acquisition of data, manuscript drafting; ET: acquisition of data, manuscript drafting; $\mathrm{OB}$ and $\mathrm{CT}$ : critical revision of the manuscript.

16. Carson PJ, Konewko P, Wold KS, Mariani P, Goli S, Bergloff P, et al. Long term clinical and neuropsychological outcomes of west nile virus infection. Clin Infect Dis. (2006) 43:723-30. doi: 10.1086/506939

17. Patel H, Sander B, Nelder MP, Petersen L, Brault A, Nasci R, et al. Long-term sequelae of West Nile virus-related illness: a systematic review. Lancet Infect Dis. (2015) 15:951-9. doi: 10.1016/S1473-3099(15)00134-6

18. DeBiasi RL, Tyler KL. West Nile virus meningoencephalitis. Nat Clin Pract Neurol. (2006) 2:264-75. doi: 10.1038/ncpneuro0176

19. Luo H, Wang $T$. Recent advances in understanding West Nile virus host immunity and viral pathogenesis. F1000Res. (2018) 7:338. doi: 10.12688/f1000research.13362.1

20. Suen W, Prow N, Hall R, Bielefeldt-ohmann h. mechanism of west nile virus neuroinvasion: a critical appraisal. Viruses (2014) 6:2796-825. doi: $10.3390 / v 6072796$

21. Suthar MS, Diamond MS, Gale Jr M. West Nile virus infection and immunity. Nat Rev Microbiol. (2013) 11:115-28. doi: 10.1038/nrmicro2950

22. Cho H, Proll SC, Szretter KJ, Katze MG, Gale Jr M, Diamond MS Differential innate immune response programs in neuronal subtypes determine susceptibility to infection in the brain by positive-stranded RNA viruses. Nat Med. (2013) 19:458. doi: 10.1038/nm.3108

23. Lucas TM, Richner JM, Diamond MS. The Interferon-stimulated gene Ifi27l2a restricts west nile virus infection and pathogenesis in a cell-type- and regionspecific manner. J Virol. (2015) 90:2600-15. doi: 10.1128/JVI.02463-15

24. Huhn GD, Dworkin MS. Rash as a prognostic factor in West Nile virus disease. Clin Infect Dis. (2006) 43:388-9. doi: 10.1086/505606

25. Sejvar JJ, Haddad MB, Tierney BC, Campbell GL, Marfin AA, Gerpen JA, et al. Neurologic manifestations and outcome of west nile virus infection. JAMA (2003) 290:511. doi: 10.1001/jama.290.4.511

26. Burton JM, Kern RZ, Halliday W, Mikulis D, Brunton J, Fearon M, et al. Neurological manifestations of West Nile virus infection. Can J Neurol Sci. (2004) 31:185-93. doi: 10.1017/S0317167100053828

27. Popescu A, Jain S, Massier A, Gopalakrishna KV, Bambakidis P, Nichter $\mathrm{CA}$, et al. West nile infection presenting with ocular dysmetria, ataxia, and hyperreflexia reminiscent of bickerstaff's encephalitis. Am J Med. (2008) 121:e3-4. doi: 10.1016/j.amjmed.2007.12.006

28. Gomez AJ, Waggoner JJ, Itoh M, Hollander SA, Gutierrez KM, Budvytiene I, et al. Fatal west nile virus encephalitis in a heart transplant recipient. J Clin Microbiol. (2015) 53:2749-52. doi: 10.1128/JCM.00834-15

29. Kanagarajan K, Ganesh S, Alakhras M, Go ES, Recco RA, Zaman MM. West nile virus infection presenting as cerebellar ataxia and fever: case report. South Med J. (2003) 96:600-1. doi: 10.1097/01.SMJ.0000054912.04257.DC

30. Khosla JS, Edelman MJ, Kennedy N, Reich SG. West Nile virus presenting as opsoclonus-myoclonus cerebellar ataxia. Neurology (2005) 64:1095-5. doi: 10.1212/01.WNL.0000154469.27522.EC

31. Nichter CA, Pavlakis SG, Shaikh U, Cherian KA, Dobrosyzcki J, Porricolo ME, et al. Rhombencephalitis caused by West Nile fever virus. Neurology (2000) 55:153. doi: 10.1212/WNL.55.1.153 
32. Afzal A, Ashraf S, Shamim S. Opsoclonus myoclonus syndrome: an unusual presentation for West Nile virus encephalitis. Proceedings (2014) 27:108-10. doi: 10.1080/08998280.2014.11929073

33. Bîrlutiu V, Bîrlutiu RM, Klaas J, Ahlskog J, Pittock S, Matsumoto J, et al. Opsoclonus-myoclonus syndrome attributable to West Nile encephalitis: a case report. J Med Case Rep. (2014) 8:232. doi: 10.1186/1752-1947-8-232

34. Hébert J, Armstrong D, Daneman N, Jain JD, Perry J. Adult-onset opsoclonus-myoclonus syndrome due to West Nile Virus treated with intravenous immunoglobulin. J Neurovirol. (2016) 23:158-9. doi: 10.1007/s13365-016-0470-3

35. Alshekhlee A, Sultan B, Chandar K. Opsoclonus persisting during sleep in west nile encephalitis. Arch Neurol. (2006) 63:1324. doi: 10.1001/archneur.63.9.1324

36. Rasmussen EW, Ballas ZK. Immune dysregulation in West Nile Virus encephalitis causing opsoclonusmyoclonus syndrome (OMS). In: 2017 Annual Meeting Immune Deficiency \& Dysregulation North American Coference. Seattle, WA (2017).

37. Shellenback L, Propst J, Avalon N, Franco PM, Canabal J, Freeman $\mathrm{W}$, et al. West Nile virus encephalitis presenting as opsoclonusmyoclonus and alterations of consciousness in a post-liver transplant patient receiving immunosuppression. Crit Care Med. (2012) 40:1-328. doi: 10.1097/01.ccm.0000425452.16938.00

38. Tan K, Kianirad Y, Zadikoff C, Bega D. Adult onset opsoclonus-myoclonus ataxia syndrome due to West Nile virus: two case reports (P2.314). Neurology (2017) 88 (16 Suppl.).

39. Zaltzman R, Klein C, Gordon CR. Opsoclonus myoclonus ataxia associated with West Nile virus infection: a dramatic presentation with benign prognosis? J Neurol Sci. (2017) 376:38-41. doi: 10.1016/j.jns.2017. 02.057

40. Prasad S, Brown MJ, Galetta SL. Transient downbeat nystagmus from West Nile virus encephalomyelitis. Neurology (2006) 66:1599-600. doi: 10.1212/01.wnl.0000216267.34612.ad

41. Lemos J, Eggenberger E. Saccadic intrusions. Curr Opin Neurol. (2013) 26:5966. doi: 10.1097/WCO.0b013e32835c5eld

42. Wong A. An update on opsoclonus. Curr Opin Neurol. (2007) 20:25-31. doi: 10.1097/WCO.0b013e3280126b51

43. Mustafa M, Levin J, Schöberl F, Rominger A. Postinfectious opsoclonusmyoclonus syndrome in a 41-year-old patient-visualizing hyperactivation in deep cerebellar nuclei by cerebral $\left[{ }^{18}\right.$ F]-FDG- PET. J Neuroimaging (2015) 25:683-5. doi: 10.1111/jon.12204
44. Helmchen C, Rambold H, Sprenger A, Erdmann C, Binkofski F. Cerebellar activation in opsoclonus. Neurology (2003) 61:412-5. doi: 10.1212/01.WNL.0000073271.66866.51

45. D'aes T, Mariën P. Cognitive and affective disturbances following focal brainstem lesions: a review and report of three cases. Cerebellum (2015) 14:317-40. doi: 10.1007/s12311-014-0626-8

46. Attig E, I Botez M, Hublet C, Vervonck C, Jacquy J, Capon A. Cerebral crossed diaschisis caused by cerebellar lesion: role of the cerebellum in mental functions. Rev Neurol. (1991) 147:200-7.

47. Ibáñez-Juliá M-J, Pappa E, Gaymard B, Leclercq D, Hautefort C, Tilikete C, et al. Brain volumetric analysis and cortical thickness in adults with saccadic intrusions (ocular flutter or opsoclonus-myoclonus syndrome). Clin Neurol Neurosurg. (2017) 163:167-72. doi: 10.1016/j.clineuro.2017.10.028

48. Hart J, Tillman G, Kraut MA, Chiang H-S, Strain JF, Li Y, et al. West Nile virus neuroinvasive disease: neurological manifestations and prospective longitudinal outcomes. BMC Infect Dis. (2014) 14:248. doi: 10.1186/1471-2334-14-248

49. Agrawal AG, Petersen LR. Human immunoglobulin as a treatment for west nile virus infection. J Infect Dis. (2003) 188:1-4. doi: 10.1086/376871

50. O'Leary DR, Marfin AA, Montgomery SP, Kipp AM, Lehman JA, Biggerstaff BJ, et al. The epidemic of west nile virus in the United States, 2002. VectorBorne Zoonotic Dis (2004) 4:61-70. doi: 10.1089/153036604773083004

51. Sejvar JJ. Clinical manifestations and outcomes of West Nile Virus Infection. Viruses (2014) 6:606-23. doi: 10.3390/v6020606

52. Murray KO, Garcia MN, Rahbar MH, Martinez D, Khuwaja SA, Arafat RR, et al. Survival analysis, long-term outcomes, and percentage of recovery up to 8 years post-infection among the houston West Nile Virus cohort. PLOS ONE (2014) 9:e102953. doi: 10.1371/journal.pone.0102953

Conflict of Interest Statement: The authors declare that the research was conducted in the absence of any commercial or financial relationships that could be construed as a potential conflict of interest.

Copyright (C) 2018 Radu, Terecoasă, Ene, Băjenaru and Tiu. This is an open-access article distributed under the terms of the Creative Commons Attribution License (CC BY). The use, distribution or reproduction in other forums is permitted, provided the original author(s) and the copyright owner(s) are credited and that the original publication in this journal is cited, in accordance with accepted academic practice. No use, distribution or reproduction is permitted which does not comply with these terms. 